\title{
A Fruit Tree as an Identification Element of Ornamental Gardens Shaping in Croatia- Istria Ornamental Gardens Case
}

\author{
Alka TURALIJA ${ }^{1}$, Anica PERKOVIĆ ${ }^{1}$, Jasenka VIZENTANER², Jasna AVDIĆ ${ }^{3}$, Vladimir JUKIĆ ${ }^{1}$, Dražen \\ HORVAT $^{1}$ \\ ${ }^{1}$ Universty J.Juraj Strossmayer, Faculty of Agriculture in Osijek, Kralja Petra Svačića 1 D, Osijek, Croatia \\ ${ }^{2}$ Čarobni tim d.o.o., Eugena Savojskog 49, Podravlje Osijek, Croatia \\ ${ }^{3}$ Faculty of Agriculture and Food Sciences, University of Sarajevo, Bosnia and Herzegovina \\ *)Corresponding author, e-mail: alka.turalija@pfos.hr
}

BulletinUASVM Horticulture 74(1) / 2017

Print ISSN 1843-5254, Electronic ISSN 1843-5394

DOI:10.15835/buasvmcn-hort:12369

\begin{abstract}
A fruit tree has always been a determinant of an ornamental garden shaping in Croatia. From the 13th century onward an organized planting of fruit trees has been recorded. A total of 100 gardens in Istria have been analysed, 50 of which were examined in the Istria interior, and 50 in the coastal area. Due to the shape and architectural style, 8 different types of gardens were determined and classified, by the location, into three climatic-relief areas A, B and C. There were 7 types of ornamental gardens with a fruit tree as a primary determinant of the garden, except one without it. Out of the 23 recorded fruit tree species, Prunus avium (L.) L., sweet cherry, Ficus carica L., fig tree, Vitis vinifera L. vine and Olea europeaea L., olive tree and vine have been the most commonly used in the Istria interior whereas olive trees, Eriobotrya japonica (Thunb.) Lindl., Japanese loquat, fig trees and vine have been known in the Istria coast.
\end{abstract}

Keywords: architecture, fruit trees, garden, history

\section{INTRODUCTION}

The paper aims to show that fruit trees have been inevitable a part of the garden design in Croatia both in the past and today. As for the garden architecture, they have been located on different places depending on the house architecture and historical period.

While observing the development of historical garden architecture in Croatia there is a very short period of written historical documents on ornamental gardens look and contents. The ornamental garden in this study is defined as an enclosed (fenced) or open (unfenced) area around the house (private plot) but also as a front garden that can and does not have to create an entirety together with a private plot. Taking into account the historical records, photos and analysis of traditional habits and housing, presence of fruit trees has been recorded as constant in private gardens in Croatia. Thus, we can talk about the determinant element that made the garden design unique in Croatia and managed to preserve traditional and indigenous fruit species over the centuries. A fruit tree has been regardless aesthetic value, the source of food for people and domestic animals. Therefore, more fruit species were planted in the past than today nowadays they are replaced by new ornamental species and cultivars. Fruit trees associated with other ornamental plant species are traditional and can be observed in all parts of Croatia, both in the past and today. So today, when the whole world is aware of the importance of sustainable development and biodiversity conservation, traditional fruit species are becoming important not only for ornamental garden composition, but also for the future commercial fruit production including the selection of fruit crops which is 
less demanding and more resistant for organic farming purposes. Most of old sorts of fruit trees have been kept just within ornamental gardens. The diversity and viability of fruit species have been related to gastronomy and sometimes to old stories and different beliefs. The shape of the garden changes along with the climaticrelief structure, typical traditional architecture of dwelling-houses, but is also related to the historical genesis. All of these elements and their analysis will provide a unique image of traditional design values and the review of the present ornamental gardens situations in Croatia. Ornamental gardens of Istria are analysed and presented in this paper.

History of fruit species cultivation goes back far in the past. Apples, olives, figs, almonds, grapes and other fruits species are mentioned as a part of the Eden's Garden. Adam and Eve wore "clothes" made of the fig leaf, and Eve ate the forbidden fruit - an apple. Still today, fruit has a particular religious value in many cultures, and sometimes it is described as the God's (or gods) consumed elixir. The oldest record on fruit tree species cultivation originates from the ancient Egypt period i.e. 8000 years B.C. when fruit trees plantings were found along the Egypt and Sudan border. There were only groups of nomadic hunters various tribes. Most of the fruit tree species came in Europe from the eastern countries, Persia, China, Asia and Japan, while the berries were brought from North America. Prunus domestica L., common plums, Pyrus communis L., common pears and Fragaria vesca L., strawberries have always grown in Europe and other fruit trees have been mostly brought in Europe by the Greeks and Romans. The Turks have also been meritorious for fruits expansion and breeding in the Croatian territory. Croatian territory, "acorn-bearing Pannonia regions were...", has been mentioned in Stephen Sršan's translation of Mathia P. Katancsich "Comment of Pannonia Gaius Pliny the Elder". "From there, the Pannonia, famous for people, plain and fertile soil, was inundated by the known rivers Drava and Sava...." Trees, fruits trees and herbs have been mentioned in the plants description (Sršan, S., 1991).

The culture of growing fruit trees in Croatia can also be recorded for centuries throughout the history. In the 13th century Dubrovnik people grew fruit trees, mainly Citrus aurantium L., bittersweet oranges on their country estates (Sisic, B., 1991). There is a country house complex layout of Peter Sorkočević on Lapad coastal area of approximately $3900 \mathrm{~m}^{2}$ with an orange garden from 1521 (Sisic, B., 1991). Records of fruit and orchards cultivation as well as fruit species cultivation and grafting including some of our domestic varieties of pears and apples are found in Zrinski family in the 16th century. Tradition of cultivating fruit trees in this family continued through several generations, and a passionate fan of gardening and horticulture was Nikola VII Zrinski (1620-1664) who was especially proud of his beautiful peaches and who wrote a manual on breeding and grafting fruit trees in Latin entitled: DE ARBORUM PLANTATI ONIBUS ET INSITIONIBUS- Fruit Trees Planting and Grafting (Varga, D., 2014). The Zrinskis produced fruits and fruit trees for themselves and for sale. It should be noted that Nikola VII Zrinski was a true collector of fruit species and had planted a garden and an orchard admired by all learned men and enlighteners. In the 18th and 19th centuries when Maria Theresa reigned, the nobility in Croatia began to organize fruits cultivation, even tropical fruits. The Prandau family from Valpovo has grown pineapple and citrus, particularly lemons and sweet oranges whereas various types of fruit trees such as pears, apples, plums, etc. were planted within the orchards. They produced plum brandy and sold it (Perči, Lj., 2007). Use of fruits in gastronomy has been taken from the Italians and our nobility used it in a way to secure a sufficient fruit throughout the year and organize orchards and vineyards planting, as well as citrus and pineapple cultivation in greenhouses. In the Secession period, at the end of 19th and early 20th century, records on the fruit trees, fruit and fruit products export can be found. The Baron Gustav Prandau family from Valpova, in its exhibition catalogue on The nursery-garden in Donji Miholjac in 1881, stated the 148 varieties of dwarf fruit trees (Turalija, A, and Šetić, N., 2006). The first records and studies on organized fruit-growing in Croatia and its profession were written by I. Radic in 1898, in his book "Fruit growing: By the best sources and their own experience."

The tradition of shaping gardens with residential houses in Croatia as well as in other parts of 
Europe has been related to several elements and historical development phases of society and architecture:

- social status and financial power

- the different geographical region where the garden is located regarding the climate and relief

- tradition of shaping, growing and care of ornamental plant species

- benefits the plant species gives, i.e. the purpose of planting which was first explicitly for food sources or to provide shade or wind protection

From the Romans and Roman garden architecture, whose remains are found on many archaeological sites in the whole Croatian territory and where the first written records on instructions for gardening has been located from 27th B.C. archaeological researches have shown that the gardens were an integral part of the rich Roman villas. Fruit species, particularly citrus fruits have been found in their designing and composition. From the first beginnings of Catholicism and monastery gardens in the Middle Ages, when the monks cultivated fruits and practiced the selection, to the Renaissance garden (Dubrovnik Renaissance Garden) fruit trees have continually been determinant of garden shaping and composition in Croatia. Dr. Bruno Šišić prominent landscape architect emphasized the value and uniqueness of Dubrovnik Renaissance garden. He wrote "From a single incidence of designing gardens around the houses of commoners from the 16th century there has been a description of the yard being muddy and untidy. However, some fruit species, usually Juglans regia L., common walnut or Morus L., mulberry have been almost always found within it." The presence of trees within the serfs' yards is also evident within the Julian registry. The social status in the 17 th and 18 th centuries imposed a different trend in gardens and parks design. Although the nobility set up parks around their castles, palaces, and manors in which there were mostly groups of trees, shrubs and exotics, one could find some fruit tree as well. They were mostly parks designed using the French model of the formal garden or English park. At that time they established special economic areas and arranged orchards which were used both for the personal benefits and as a production area where they grew fruits for sale or for fruit products preparation.
Orchards were mostly related to the park or located on the special properties (villas, manors, estates including vineyards, orchards, fields and forests along the zoological gardens). So, fruit trees have been a determinant of the incidence of the parks and gardens design in Croatia for centuries till today. Some fruit varieties have become popular as ornamental plant species (pendula-like Morus L., mulberry, Musa L., "palm" bananas etc.), and others were planted on special places for the sake of mythical beliefs (common walnut, Cornus mas L., cornel berry).

\section{MATERIALS AND METHODS}

Expert and scientific literature has been studied whereas a part of the research was conducted in the field where the shape and structure of the private plots and gardens were determined. Also plant species, particularly fruit trees, have been determined here. The paper was written in Word 2016 whereas the layout position of fruit trees planting within the gardens and private plots was presented in Corel Draw X6 (version 2013). The frequency of certain plant species incidences was elaborated in percentage and shown in the graph. During the field trips, the Olympus photos have been taken and display of the selected photos was inserted in the tabled part of the paper. The continuity of the fruit tree species incidence as an ornamental element in the garden and the survival of indigenous and traditional sorts, are not sufficiently commercially exploited, have been presented in the first out of the seven forthcoming papers. Also, gardens have been analysed by the design, traditional architecture, population habits, different entities (19 entities) cultural affiliation as well as their economic utilization. They were described within 7 different regions (Map 1). A part of the Region 1 referring to Istria has been described in the paper. A position of fruit trees relative to historical and traditional garden design has been analysed on the sample of 100 randomly selected gardens.

\section{RESULTS AND DISCUSSIONS}

There are different gardens design and different fruit species choice within 16 landscape regions divided in Croatia by the diversity of climate and relief. In the coastal area (Adriatic Sea) and the islands as well as in the interior we come across to different types of fruit, but also to 
Map. 1. Regions by the landscape basis of Croatia

Design: J. Vizentaner, 2016

Source: B. Aničić, 1999

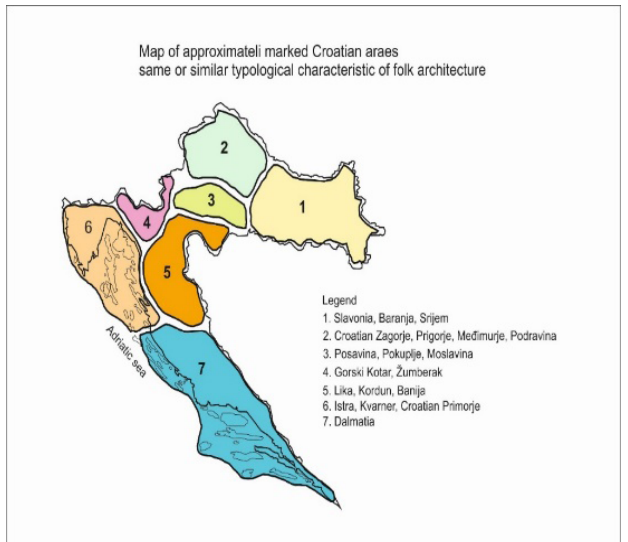

Map. 3. Fruit tree or fruit tree growing regions in Croatia; Source: Z. Čmelik, 2009
Map. 3. Garden's location Source: A. Turalija, 2016
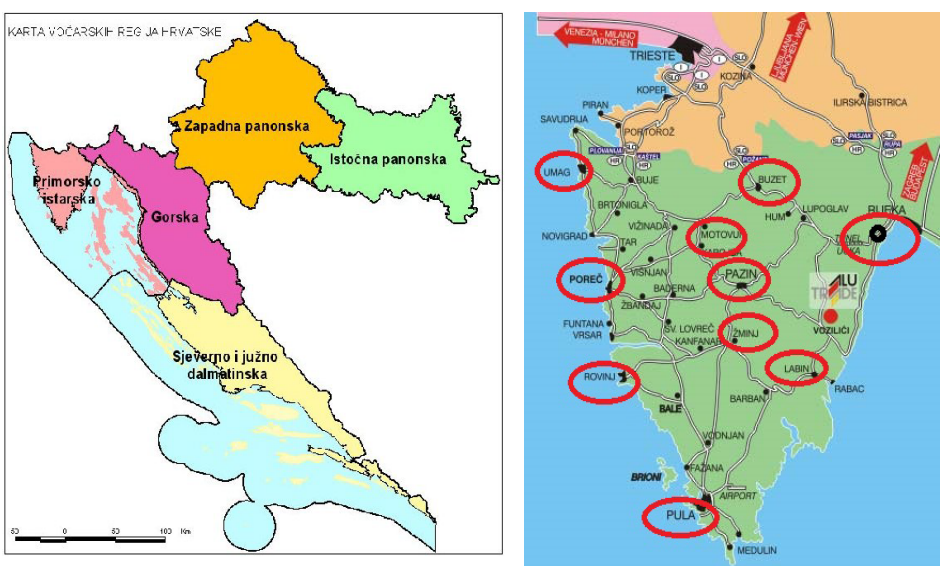

the different approach of the yard organization. It is interesting that the continental part is today known for increasing presence of fruit species belonging to the Mediterranean climate, even the tropics. The variety of plant species design and selection will be presented by regions and finally the diversity of fruit species will be summarized in the table.

Gardens designs vary by type regarding the historical sequence and heritage. Thus we have:

1. Historical style - which follows the historical and cultural heritage representing cultural heritage affiliation of architecture style or historical heritage with certain specific qualities. The oldest house eg. in Pula dates back from $1270^{\text {th }}$, and the historical changes are characteristic for certain historical periods. Characteristic traditional Istrian houses - stanzie (from Italian stanza $=$ room) are organized in a way that yard is known for series of farm buildings whereas the main house (usually one-story or two-story building) used for housing had tavern and Kuzin with a fireplace on the ground floor. Bedrooms for a large family were upstairs - cooperative economy type (Demonja, D. and Baćac, R., 2013). Such a construction type, where a kitchen has an underground location, leading directly to the garden is still actual today. (Examples: Motovun, Renaissance and Secession gardens with villas in Opatija) -Type of garden

2. Traditional style - which is present today in the recent architecture (1960-1990), by the traditional heritage as an entity of the cultural heritage of nations and nationalities living in Istria (example: Žminj) - Type of garden 2

3. Historical-traditional style - which is a determinant of Croatian landscape value representing the historical cultural heritage of mostly rural areas, but also the specific architecture of the cities in the interior and coastal area of Istria (example: Žminj) - Type of garden 3

4. Modern style with traditional elements (the most common occurrence of garden architecture from the Second World War till today, simple and fits into the modern architecture of urban settlements where fruit trees retain their traditional role in the garden design being present in all Croatian parts (examples: Umag) - Type of garden 4

5. Modern style without traditional elements belongs to modern villas and residential houses - Type of garden 5

The division of the observed climatic and relief regions (according to which the diversity of the gardens was observed and recorded, which are analyzed in this paper by the architecture genesis), is shown on the map no. 1 defined within the document Content and Methodological Basis of Croatian Landscape Value ${ }^{1}$. The Croatian fruit regions can be seen on the map 2 (Čmelik, Z., 2009), and locations of analyzed gardens by places location in Istria where the gardens photos were taken are on the map 3. 


\section{Historical typology of the garden architecture by the regions and relief landscape structure}

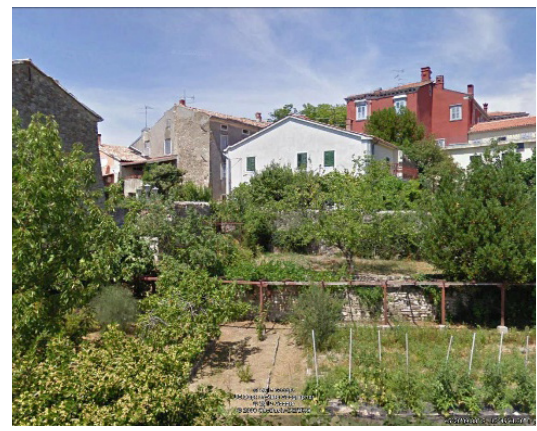

Fig. 1. Motovun - interior of Istria, a city on a hill. TYPE of the garden I - 1 (A).

The historical-traditional style within the historic zone belonging to 0 category of cultural heritage protection.

Source: A. Turalija, 2014

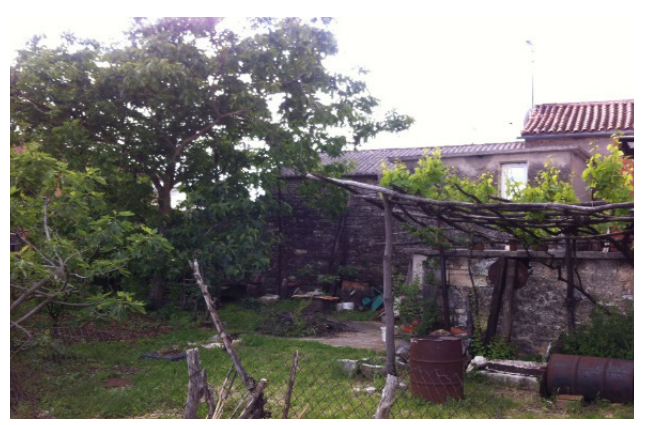

Fig. 2. Traditional stone house in the central part of Istria, Žminj.

TYPE of the garden II - 3 (B). Historically traditional style.

Source: A. Turalija, 2014.

\section{Design and position of the fruit trees and fruit trees in the garden with design description}

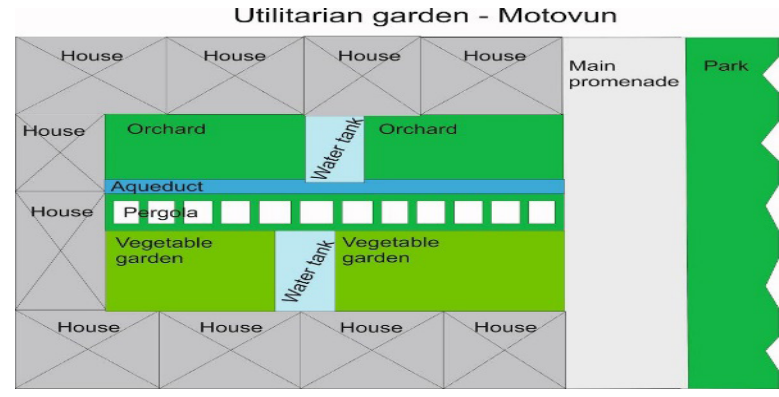

Source: J. Vizentaner; A. Turalija, 2016.

Typical traditional utilitarian gardens in the mountainous area of Istria surrounded by residential buildings protecting them from the wind and winter. Each garden has a water source, be it well or aqueduct, surveying water from the central water tank being, in this example located on a higher market level collecting rainwater. Garden areas are symmetrically divided and Buxus sempervirens L., boxwood or Rosmarinus officinalis L., rosemary hedges lined.

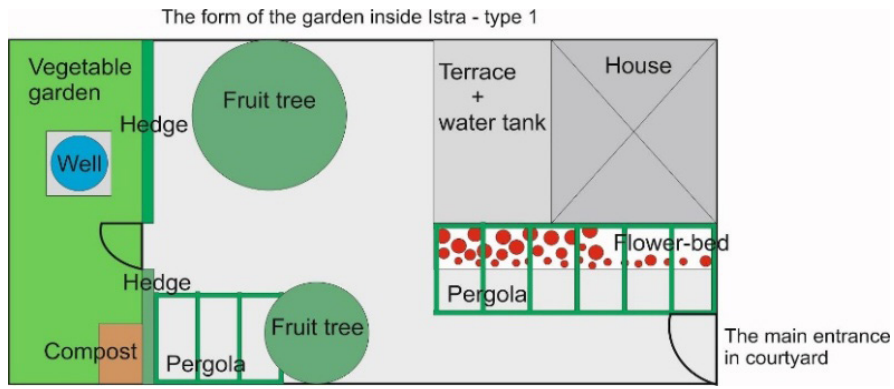

Source: J. Vizentaner; A. Turalija, 2016.

The yard is divided into two parts: the ornamental style along the house where there are fruit trees (common walnut and fig) and vegetable garden separated by the green fence; vine pergola (Vitis vinifera L. 'Istrian Malvasia') and flower garden. Animals were used to be housed in dwellings being the ground floor of the house in which people lived due to easier doing operations and care they need in winter, or were leaning against the house.
Thus, in Istria there are several different garden designs that can be identified depending on the location of the garden:

1 garden on high hills surrounded by fields or forests (A)

2 garden within the lowland part of the Istria interior (B)

3 garden along the coastal area (C)
A total of 100 gardens have been examined. Fifty gardens from the interior of Istria have been analyzed in the following places: Motovun, Rovinj, Labin, Pazin, Buzet whereas 50 gardens were examined in the coastal area in the cities as follows: Pula, Umag, Poreč, Rovinj and Opatija. Eight different types of garden have been determined in terms of the shape, historical background and 


\section{Historical typology of the garden architecture by Design and position of the fruit trees and fruit trees the regions and relief landscape structure in the garden with design description}
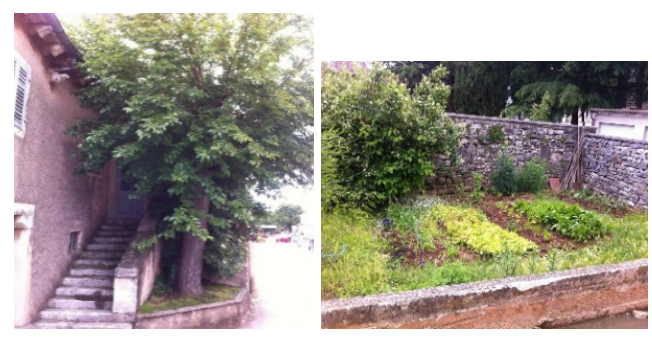

Fig. 3. Traditional type of the stone house in the interior of Istria, compact construction, Morus alba L., white mulberry planted by the house. TYPE of the garden III - 3 (B). Historically traditional style. Source: A. Turalija, 2014.

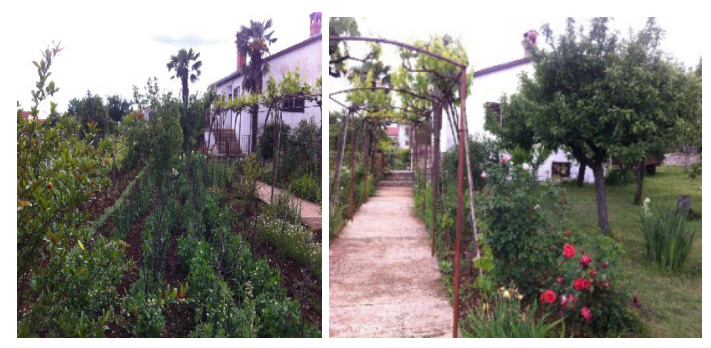

Fig. 4. Recent house construction with traditional garden architecture.

TYPE of the garden IV - 4 (B). Traditional style with recent architecture

Source: A. Turalija, 2014.

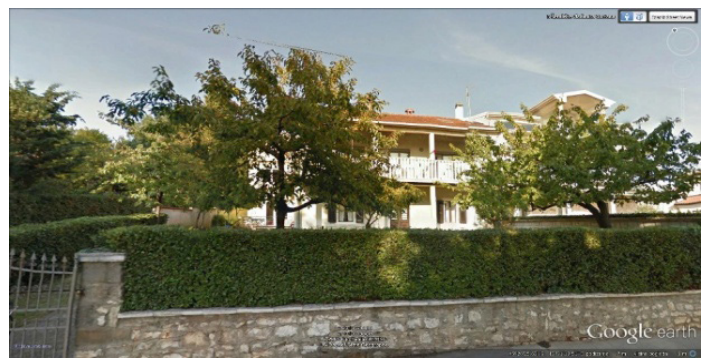

Fig. 5. A recent construction type along the coast. TYPE of the garden V - 4 (C). Fruit trees are traditionally present in the front garden with strictly simple, symmetrical,

formal garden architecture design. Traditional style in a modern garden architecture. Source: A. Turalija, 2014.

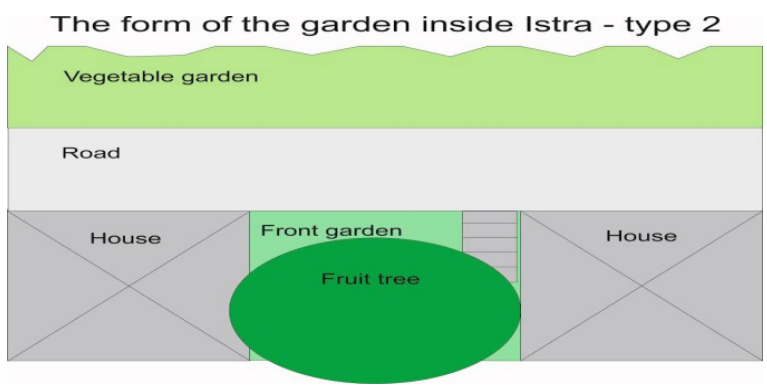

Source: J. Vizentaner; A. Turalija, 2016.

This type of the compact settlement construction and narrow streets due to wind and sun protection in summer, has a planted fruit by the house whereas the garden is located opposite other street side is surrounded by the stone walls. Livestock and fields were located outside the place, and the houses were used exclusively for housing. Even the smallest room where the fruit tree could be grown is properly used. Some fruit trees or vine covering drywall were also located within the vegetable garden.

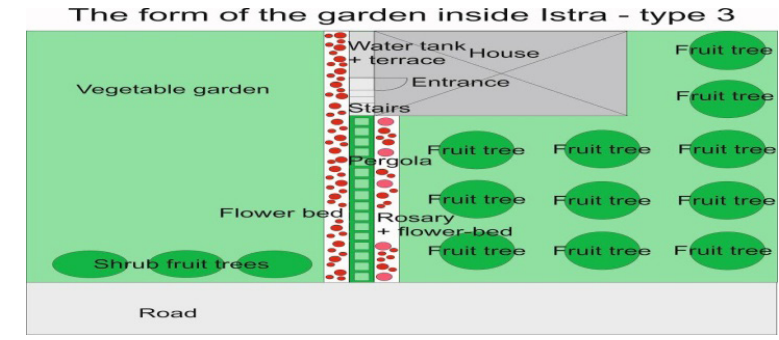

Source: J. Vizentaner; A. Turalija, 2016.

The house is set back from the street the main access road vine covered pergolas can be found. The garden is divided into several parts: the orchard, a small vineyard, a vegetable garden including an ornamental garden being interwoven into each of the separated garden parts with the emphasized main access road

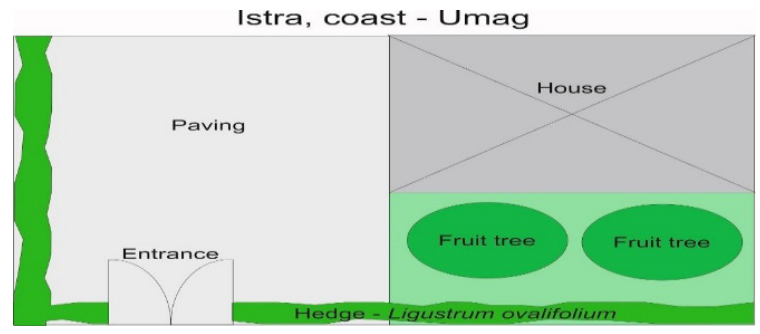

Source: J Vizentaner; A. Turalija, 2016.

This is a standard example of architectural design in the recent private houses construction along the Istria coast. The garden is simple, with a thick, mainly, Prunus laurocerasus L., laurel cherry or Laurus nobilis L., laurel hedge. Recently, Photinia $\times$ fraseri Dress. 'Red Robin', photinia is used as a fenced plant species. There is no flower garden but pergola or twining plants appear or even clay or ceramic decorative pots with seasonal flowers or citrus with a few twining plants or a shrub-like rose. 


\section{Historical typology of the garden architecture by the regions and relief landscape structure}

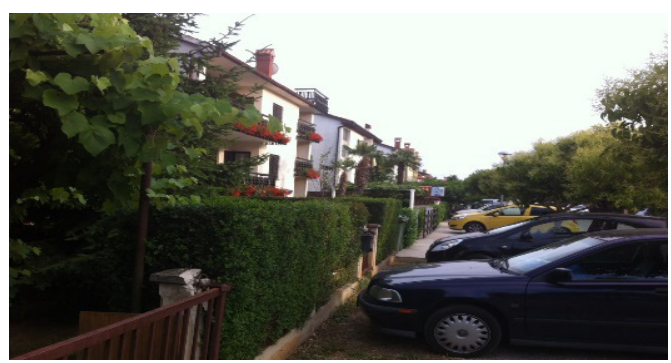

\section{Design and position of the fruit trees and fruit trees in the garden with design description}

Fig. 6. a) and b) Recent settlements building in the coastal region Line- set houses of the formal garden architecture with a fruit tree of Istria-Umag. Private houses in the standard row. TYPE of the as a traditional element in the front garden area and vine pergola. garden VI - 4 (C). Modern building with a traditional garden There is no flower garden except entrance twining plants or shrubarchitecture style. Source: A. Turalija, 2015. like rose.

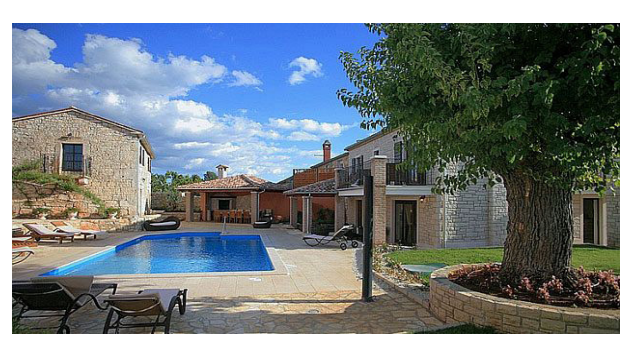

Fig. 7. Reconstruction of traditional houses in the interior of Istria.

TYPE of the garden VII - 2 (B). Modern style with traditional detail and architecture design of the building. The old white mulberry is remained.

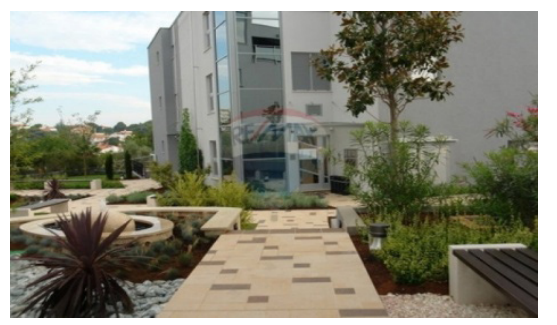

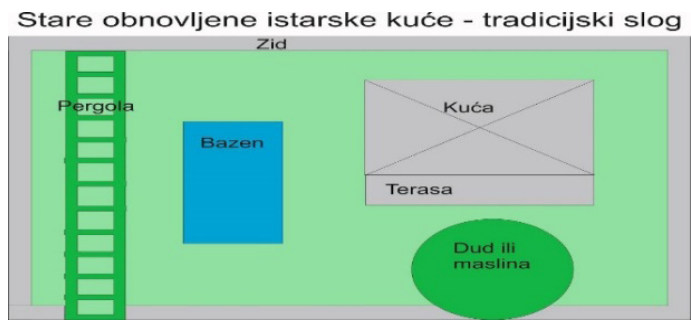

Source: J. Vizentaner, A. Turalija, 2016.

The renovation respected the historic architecture here, but the old farm complex gets new contents necessary for the tourism development: swimming pool, tennis court, garages and parking lots for cars. The fruit tree has remained here, along with modern architecture, as a part of the central axis and traditional architecture including design.

Fig. 8. Modern garden, with urban villas, which does not include the traditional elements, is characterized by no fruit species. New materials (plexiglas, concrete paving) appear and plant species (Cordyline australis Hook, cabbage tree or Bambusa vulgaris Sharad ex Wendl, bamboo) are imported from different parts of the world for the sake of prestige and prosperity. TYPE of the garden VIII - 5

(C); Source: A. Turalija, 2015. traditional elements the garden contains whereas selected examples were shown by the layout and photographs. A table with a list of fruit trees found in gardens was designed whereas their number, in relation to the number of the examined gardens, was recorded as well as frequency of occurrence in terms of the Istria interior including the coastal area, i.e. in relation to two different areas regarding climate and relief. The position of fruit trees within the garden was determined whereas gardens have been divided by the shape of their location and the historical affiliation of the historical development including formal and informal style. 
Tab. 1. Fruit sp. incidence in the total of 100 gardens and particularly in the interior and coastal area

\begin{tabular}{|c|c|c|c|c|}
\hline $\begin{array}{l}\text { Ordinal } \\
\text { no. }\end{array}$ & Latin and Croatian name of the fruit tree & $\begin{array}{l}\text { Frequency of the } \\
\text { incidence within } \\
\text { the sample of } 100 \\
\text { gardens in Istria }\end{array}$ & $\begin{array}{l}\text { Frequency of the } \\
\text { incidence in the } \\
\text { continental part on } \\
\text { the sample of } 50 \\
\text { gardens }\end{array}$ & $\begin{array}{c}\text { Frequency of the } \\
\text { incidence in the } \\
\text { coastal part on } \\
\text { the sample of } 50 \\
\text { gardens } \\
\end{array}$ \\
\hline 1. & $\begin{array}{l}\text { Vitis vinifera L., vinova loza. Istria sorts: } \\
\text { Istarska Malvazija, Teran }\end{array}$ & 92 & 46 & 46 \\
\hline 2. & $\begin{array}{l}\text { Olea europea L., maslina. Old sorts: } \\
\text { Črnica, Istarska Bjelica, Buža, Rošinjola }\end{array}$ & 89 & 43 & 46 \\
\hline 3. & $\begin{array}{c}\text { Ficus carica L., figa, smokva. } \\
\text { Old sorts: Bjelica, Petrovača Bijela, } \\
\text { Petrovača Crna, }\end{array}$ & 86 & 36 & 46 \\
\hline 4. & $\begin{array}{l}\text { Prunus avium (L.) L., čerišnja, črešnja, } \\
\text { črišnja, trešnja . Old sort: Črešnja }\end{array}$ & 64 & 46 & 18 \\
\hline 5. & $\begin{array}{l}\text { Eriobotrya japonica (Thunb.) Lindl., } \\
\text { japanska mušmula, nešpula, nešpola }\end{array}$ & 64 & 26 & 38 \\
\hline 6. & Juglans regia L., oreh, orah,ureh & 62 & 43 & 19 \\
\hline 7. & $\begin{array}{l}\text { Prunus cerasifera Ehrh., kreka, šljiva. old } \\
\text { sort: Kreka (bijela) }\end{array}$ & 57 & 39 & 18 \\
\hline 8. & Punica granatum L., nar, šipak, šipek & 33 & 12 & 21 \\
\hline 9. & $\begin{array}{l}\text { Malus domestica Borkh., jabuka. } \\
\text { Old sorts; Belica Petrovka or Petrovača, } \\
\text { Citronka }\end{array}$ & 33 & 17 & 16 \\
\hline 10. & $\begin{array}{l}\text { Pyrus communis L., kruška } \\
\text { Old sort: Tikvica }\end{array}$ & 27 & 13 & 14 \\
\hline 11. & Prunus persica (L.) Batsch, breskva & 23 & 11 & 12 \\
\hline 12. & Cydonia oblonga Mill., dunja, gunja, & 17 & 14 & 3 \\
\hline 13. & Morus alba L./M. nigra L., dud, murva & 14 & 11 & 3 \\
\hline 14. & $\begin{array}{l}\text { Corylus avellana L., obična lijeska, } \\
\text { lješnjak }\end{array}$ & 14 & 9 & 5 \\
\hline 15. & $\begin{array}{l}\text { Prunus dulcis (Mill.) D. A. Webb var. } \\
\text { dulcis, badem, bajam, mendul, mjendul, } \\
\text { mjendula }\end{array}$ & 14 & 3 & 11 \\
\hline 16. & $\begin{array}{l}\text { Prunus cerasus L., višnja, maraška, } \\
\text { maraska }\end{array}$ & 14 & 4 & 10 \\
\hline 17. & Actinidia deliciosa A. Chev, kivi & 13 & 4 & 9 \\
\hline 18. & $\begin{array}{l}\text { Citrus } \times \text { sinensis (L.) Osbeck; C. } \times \text { limon } \\
\text { (L.) Burm.f., naranče i limuni }\end{array}$ & 13 & 2 & 11 \\
\hline 19. & $\begin{array}{l}\text { Castanea sativa Mill., pitomi kesten, } \\
\text { marun, Lovranski maron }\end{array}$ & 12 & 3 & 9 \\
\hline 20. & Musa sapientum L., banana & 10 & 4 & 6 \\
\hline 21. & Diospyros kaki L. f., pomi kaki, kaki & 8 & & 8 \\
\hline 22. & Mespilus germanica L., mušmula & 3 & 3 & \\
\hline 23. & $\begin{array}{l}\text { Cornus mas L., drenak, dren, drenić, drin, } \\
\text { drenj, drinka, drijen }\end{array}$ & 3 & 3 & \\
\hline 24. & Gardens without fruit trees & 8 & 4 & 4 \\
\hline
\end{tabular}




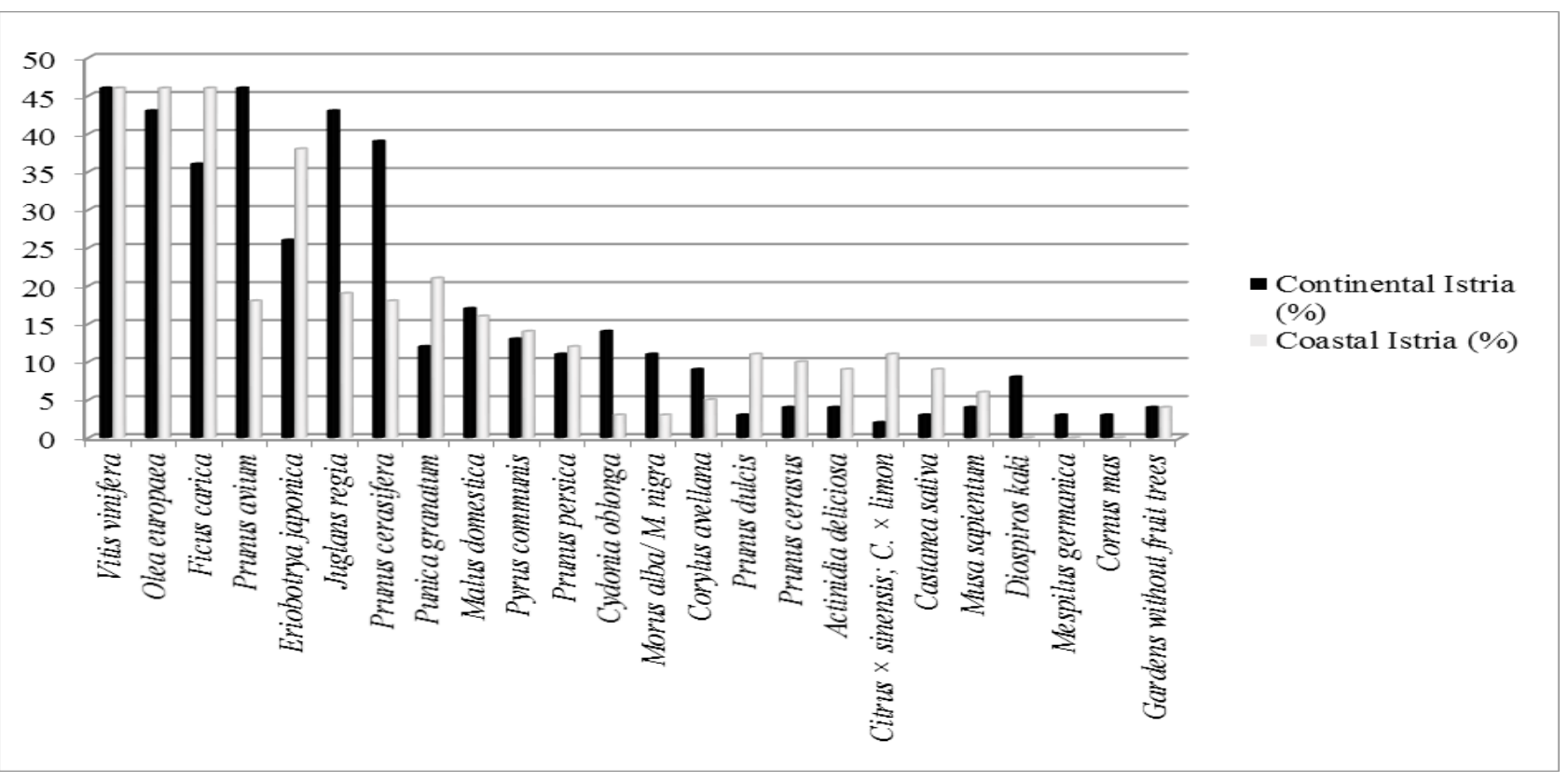

Graph. 1. The occurrence of the fruit tree species in Istria; Source: J. Vizentaner and A. Turalija

According to organization and stratification, the ornamental gardens in Istria can be divided into eight (VIII) organizational categories:

I - utilitarian garden on the elevated parts (tops of hills) being unique settlements construction in the Istria interior. The garden has been organized in the town centre serving all citizens surrounded by residential houses. It consists of strictly divided, symmetric units separated by low hedges separated units: vegetable gardens, orchards, flower and herb garden. There are a well and a pergola of vines within the garden.

II - historically traditional style along the stone houses 100 and more years aged, the yard is divided into several organized units: ornamental garden next to the house; a yard with a solitary fruit trees trunk, a terrace with a water tank below and a hedge fenced vegetable garden with fruit trees and flowers.

III - historically and traditionally organized yard with old stone houses (100 and more) where the garden is separated from the house while a fruit tree is planted close to the house and flower-garden takes part of the the vegetable garden. Plants can also be found in the window and along the stairs in pots.
IV- recent architecture of the house together with the traditional structure of the yard the garden is divided into two parts: the main walkway from the entrance with pergola and rose garden on the sides. An orchard and a vineyard can be found on one side and a vegetable garden on the other side of the garden.

$\mathrm{V}$ - recent house building (60's to 90's) along the coast is associated with traditional elements where the yard structure consists of a vehicular entrance with trellies on its sides, a front garden with two or more fruit trees including few roses or perennials. The presence of ornamental vases at the entrance of the house was also noted.

$\mathrm{VI}$ - the identical style as the V, only row houses organization and identical settlements throughout the coastal Istria area

VII - restored traditional farms with old stone houses and olive trees, mulberry, sweet cherry or fig tree as the central part of the garden, with modern elements inserted for sport and recreation (swimming pool, tennis courts and the like) were noticed

VIII - a modern construction style and the garden look with neither traditional elements nor fruit species including many exotic species and other plant species and varieties, harmonized with 
modern buildings. Recreation areas and parking lots also took part of the garden

Almost the entire collection of old and traditional Croatia fruit varieties retained to the present day especially in private gardens and private plots. Therefore, the presence of fruit species as a historical constant within gardens in Croatia is very important.

The analysis of the examined gardens in Istria (sample of 100 gardens) showed the following fruit species occurrence in Tab. 1.

Most of the total share of gardens incidence are as follows:, Vitis vinifera L., vine (92\%), Olea europaea L., olive tree (89\%), Ficus carica L., fig tree, (86\%) followed by, Prunus avium (L.) L., sweet cherry (68\%) and Eriobotrya japonica (Thunb.) Lindl., Japanese loquat (64\%). It is interesting that the four fruit species appear in 46 coastal gardens and/or continenal Istria with woody fruit trees found such as: grapes (and coastal and inland Istria), olives (coastal Istria), fig (coastal Istria) and cherry ( continental Istria). Incidence share of 12 woody fruit species in the continental or coastal part of Istria is less than 10\%: Cydonia oblonga Mill., Morus alba L. and M. nigra L., Corylus avellana, Prunus dulcis, P. cerasus, Actinidia deliciosa Fuzzy, Citrus $\times$ sinensis (L.) Osbeck and Citrus limon (L.) Burm. f., Castanea sativa Mill., Musa × paradisiaca L., Diospiros kaki L. f., Mespilus germanica L, and Cornus mas L.. Three woody fruit tree species of the mentioned ones do not appear in the coastal Istria: Mespilus germanica L., Diospiros kaki L. f., and Cornus mas L. (Tab. 1).

\section{CONCLUSION}

Croatia has a centuries-old tradition of fruit species planting within ornamental gardens, private plots as well as public green spaces. The most well-preserved traditional and indigenous plant species and varieties survived because of the traditional garden architecture where the fruit tree played a very important role.

Fruit varieties are an integral part of the gardens in Croatia. This paper clearly analyses ornamental gardens to the climate, relief and location (I-III), according to the historic origin of the garden-style architecture, traditions and their combination (1-5), and the position of fruit trees in the garden (I - VIII). The sample of 100 gardens in Istria were analysed and divided into three climatic-relief units (places on the elevated hills (A), lowland interior (B) and the coastal part (C)), eight (VIII) different garden organizational architecture and 5 different architectural styles. They are related to historical periods the garden was created, inherited or maintained (TYPE of the garden I -1 (A), TYPE of the garden II - 3 (B), TYPE of the garden III - 3 (B), TYPE of the garden IV - 4 (B), TYPE of the garden V - 4 (C), TYPE of the garden VI - 4 (C), TYPE of the garden VII - 2 (B) and TYPE of the garden VIII - 5 (C).

Out of 100 examined gardens 92 gardens containing fruit tree species have Vitis vinifera L., vine. The second important fruit tree species is Olea europaea L., olive, in 64 ornamental gardens followed by Ficus carica L., fig in 82 and Prunus avium (L.) L., sweet cherry, in 64 ornamental gardens. Morus L., mulberry, formerly being indispensable woody fruit species is now observed only in 14 ornamental gardens. It is interesting that Morus nigra L., black mulberry and Morus alba L., white mulberry was determined, but the Morus rubra L., red mulberry was not seen. Cornus mas L., cornelian cherry, naturally prevalent in the Balkan and Apennine Peninsula, Central Europe, the Crimea, Asia Minor, favouring limestone soils, was found on only 3 out of 100 localities. Since hard cornel and Mespilus germanica L., medlar tree, disappear from the ornamental gardens, not only in Istria (but in the whole Croatia), it would be appropriately to find the reasons for these species disappearance.

This paper proves significant of using fruit trees and significant of their position in ornamental gardens through history until today.

The fruit trees were and they are part of the landscape and there are the traditional values of Istria. The paper was written for the purpose of future full valorisation of landscape values.

\section{REFERENCES}

1. Aničić B (1999). Studija Krajolik, sadržajna i metodska podloga Krajobrazne osnove Hrvatske. Zagreb: 21.

2. Čmelik Z (2009). Završno Izvješće: Regionalizacija voćarske proizvodnje u Republici Hrvatskoj, Agronomski fakultet u Zagrebu, Ministarstvo poljoprivrede, ribarstva i ruralnog razvoja, Vijeće za istraživanja u poljoprivredi i seoskom području: 12.

3. Demonja D, Baćac R (2013). Ruralna graditeljska baština u funkciji turističke ponude Hrvatske, Podravina Vol. 12(23):138. 
4. Perči Lj (2007). O uzgoju limuna, ananasa i grijanim staklenicima u Valpovu, Valpovački godišnjak br 12:2948.

5. Sršan S (1991). Djela Matije Petra Katančića. Društvo prijatelja starina. Valpovo, Odjeci prošlosti, br.8: 23.

6. Šišić B (1991). Dubrovački renesansni vrt - nastajanje i oblikovna obilježja, Zavod za povijesne znanosti Hrvatske akademije znanosti i umjetnosti u Dubrovniku: 26;102.
7. Turalija, Šetić N (2006). Vrtlarija Prandau-Mailath u Donjem Miholjcu, Časopis za suvremenu povijest, Vol 38(1):297-311.

8. Varga D (2014). Voćarstvo i vrtovi Nikole VII Zrinskog u Međimurju; nastupno predavanje; 350 godina Nikole Zrinskog VII. i Novog Zrina, Čakovac:77-99. 